\title{
Belediyelerde Standart Dosya Planı Uygulamalarında Yaşanan Güçlükler
}

\author{
Challenges Encountered when Applying Standard File \\ Plan in Municipalities
}

\section{Niyazi ÇiçEK*}

\begin{abstract}
Öz
Belgeleri düzenlenmek amacıyla Milli Arşiv tarafından geliştirilen Standart Dosya Planının uygulanması sırasında çeşitli güçlükler yaşandığı bilinmektedir. Bu güçlüklerin önemli bir bölümü plandaki konu başlıklarının belediye fonksiyonlarını tam karşılamaması, bu başlıkların yeteri kadar tanımlayıcı olmaması, planın elektronik belgeler üzerinde nasıl uygulanacağının bilinmemesi, serileri oluşturacak belgelerin dosyalama anlayışındaki belirsizlik gibi çeşitli problemlerden kaynaklanmaktadır. Bu çalışmanın amacı, belirtilen problemlere çözüm yolları önermektir. İstanbul Büyükşehir Belediyesinde yürütülen dosya planı uygulamaları incelenmiştir. Görüşme, gözlem ve betimleme metodunun kullanıldığı bu çalışmanın sonucunda, güçlüklerin planın kendi içyapısından kaynaklanabildiği gibi uygulayıcıların sebep olduğu dış etkenlerden de doğabildiği anlaşılmıştır. Bu güçlüklerin, sistem yaklaşımı anlayışı içerisinde iyi tasarlanmış bir belge yönetimi programıyla aşılabileceği görülmüştür.
\end{abstract}

Anahtar sözcükler: Dosya yönetimi, Belge yönetimi, Arşivler

*Yrd. Doç. Dr.; İstanbul Üniversitesi Bilgi ve Belge Yönetimi Bölümü. (ncicek@istanbul.edu.tr) 


\section{Abstract}

There were some difficulties creating challenges that were encountered in the process of applying the Standard File Plan as developed by the National Archives Administration. An important part of these challenges originated from the fact that the subject headings do not correspond with the defined tasks and functions of the municipalities, moreover the subject headings are not descriptive enough and the application of the plan to electronic records is not clear enough. The aim of this article is to offer solutions to such problems on the basis of an illustrative example. Thus the file plan at the Istanbul Metropolitan Municipality have been studied for this article. In the conclusion of the article, which was reached by also using interviews and surveys, the difficulties caused by the plan itself, as well as the institution and staff were examined. It is to believe that a well-designed records management program by using an appropriate systems approach will much contribute in solving the problems.

Keywords: File management, Records management, Archives

\section{Giriş}

İdari ve mali özerkliğe sahip belediyeler, belde ve belde sakinlerinin müşterek hizmetlerini karşılarken yürüttükleri idari işlemler sırasında üretilen kâğıt veya elektronik belgelerin kontrol altına alınıp yönetilmesinden de sorumludur. Bu sebeple belge yönetimi sistemlerini kurup, dosya tasnif planlarını geliştirerek, arşiv depolarını düzenlemeleri; böylece, kullandıkları belgeleri kontrol altına almaları gerekir. Bu faaliyetler, belediyelerin kendi organları tarafından yürütülebildiği gibi dışardan hizmet alımı yoluyla da gerçekleştirilebilmektedir. Son dönemde Başbakanlığa bağlı Devlet Arşivleri Genel Müdürlüğü, diğer kamu kurumlarıyla beraber belediyelerde de uygulanmak üzere "Standart Dosya Planı" (SDP) adıyla bir dosya tasnif planı hazırlamıştır (Standart, 2005). Muhafazasına lüzum kalmayan evrakın yok edilmesiyle ilgili Kanun (Muhafazasına, 1988) ve Devlet Arşiv Yönetmeliği (Devlet, 1988) ile mükellef kabul edilen tüm kurumlara bir genelgeyle duyurulan bu plan, 2005 yılı içerisinde uygulamaya konulmuştur. Bir kamu kurumu olarak belediyeler de belirtilen arşiv mevzuatına tâbi olduklarından, standart dosya planını kullanmakla 
yükümlüdür. Planın amacı, kamu kurumlarında standart bir dosya tasnif programı uygulanmasını sağlamaktır. Her kurum, kendi esas faaliyetlerini göz önünde bulundurarak planı uygulayacaktır.

Böyle bir planın, organizasyonlardaki belge yönetimi çalışmalarına büyük bir ivme kazandıracağı açıktır. Ancak, kurumların daha önce geliştirdikleri dosya planlarının uygulanmasıyla ilgili olumsuz tecrübeler hatıllandığında, "bu teşebbüs de sonuçsuz kalır mı" sorusu zihinleri meşgul etmektedir. İşte bu kaygıyı giderebilmek için SDP'nin belediyelerde uygulanması sırasında yaşanan güçlükler, İstanbul Büyükşehir Belediyesinde yürütülen dosya planı çalışmaları göz önünde bulundurularak ele alınmıştır. Yazıda ilk olarak belediyelerdeki belge yönetimiyle ilgili önceden yapılmış çalışmalar değerlendirilmiş ve araştırmada kullanılan yöntem ortaya konulmuştur. İkinci kısımda Standart Dosya Planının yapısı analiz edilerek, planda belediyelerin ana hizmet alanlarııı yeri açıklanmışırı. Makalenin son kısmında ise yaşanan güçlükler sekiz başlık altında incelenmiştir.

Bir vaka incelemesi niteliğindeki bu makalede problemlerin çözümüne yönelik çeşitli tavsiyelerde bulunulmuştur. Problemler ele alınırken amaçlanan, iyi niyet ve ciddi bir gayret sonucunda geliştirildiği düşünülen Başbakanlık Standart Dosya Planını kötü göstermek değil, sadece belirtilen hususlara dikkat çekerek, planın belediyeler başta olmak üzere diğer kurumlar tarafından daha iyi kullanılmasına katkıda bulunmaktır.

\section{Önceki Çalışmalar, Araştırmanın Amacı ve Yöntem}

Türkiye'deki belediyelerde yürütülen arşiv ve belge yönetimi uygulamaları, SDP'yle başlamamıştır. Önceden de belediyelerde evrak, dosyalama ve arşiv işlemleri hakkında teori ve uygulamaya yönelik çalışmaların yapıldığı bilinmektedir.

Teorik çalışma örneklerinden birkaçına, yayın politikalarını yerel yönetim konularının oluşturduğu dergilerde rastlamaktayız. Asım Eren'in iller ve Belediyeler Dergisinde çıkan yazıları, belediyeler ve diğer kamu kurumlarındaki evrak idaresi ve arşiv işlemlerine yönelik çalışmalardır (Eren, 1952, ss. 30-32; Eren, 1953a, ss. 45-48). Bu yazılar içerisinde 
belediyelerde dosyalama işlemlerinin anlatılığı makale özellikle dikkate değerdir. Makalede Ankara ve İstanbul Belediyeleri için "desimal sisteme" göre düzenlenmiş ana konu başlıklarının yer aldığı örnek bir dosya planı verilmiştir (Eren, 1953b, s. 42-43).

Daha sonraki yıllarda karşılaşılan bazı makalelerde yurt dışındaki dosya planı uygulamalarından örnekler verildiği görülmektedir. Burhan Ergin imzasını taşıyan bir makalede Almanya'daki belediyelerde uygulanan "desimal dosya planı" verilmektedir (1962, ss. 53-54). Planda yer alan ana konu başlıkları, o yıllarda belediyelerde bulunan birimler ve yürütülen fonksiyonları yansıtması bakımından dikkat çekicidir.

Belgelerin ayıklama-imhasıyla ilgili kanun ve bu kanuna bağlı olarak çıkarılan Devlet Arşiv Yönetmeliği gibi mevzuatın kamu kurumları üzerinde bağlayıcılığı bulunduğundan belediyelerdeki arşiv çalışmaları da bu prosedürler çerçevesinde yürütülmektedir. Ancak, mevzuatın öngördüğü normların nasıl uygulanacağı, bazı durumlarda uzman görüşü gerektirmektedir. Bu yüzden ilgili mevzuatın belediyelere getirdiği yükümlülükleri ve bunların uygulanma şeklini açıklayan makalelere rastlanılmaktadır. Ali Biçer, Yerel Gündem dergisinin 1999 yılında çıkan sayılarında kaleme aldığı makalelerinde bu konuyu incelemiştir. Seri olarak yayımlanan bu yazılarda Devler Arşiv Yönetmeliği mevzuatının belediyelere getirdiği yükümlülükler ele alınmıştır (Biçer, 1999).

Belediyelerdeki arşiv hizmetlerine yönelik kuramsal yayınlar yanında uygulamaya dönük çalışmalar yapıldığı da bilinmektedir. Bu çalışmaların, arşiv depolarının düzenlenmesi, belgelerin elektronik ortama aktarıması ve dosya planı hazırlanması şeklinde gerçekleştirildiği görülmektedir.

İstanbul Büyükşehir Belediyesi (IBB) de dâhil olmak üzere çeşitli belediyelerde, hem profesyonel olarak hem de öğrencilerin arşiv stajı uygulamaları gibi farkı çalışmalar kapsamında, projeler geliştirilerek belge yönetimi uygulamaları yapıldığı bilinmektedir. Bu uygulamaların ilk örneklerinden biri Üsküdar Belediyesinde gerçekleştirlmiştir. Bu uygulama çalışmasının sonucu, yayın olarak bilim dünyasına kazandııımışıır (Kandur, 1998). Ayrıca, bu dönemde belediye arşivleri üzerine yapılan araştırmalar da dikkate değer niteliktedir. Oğuz 
İçimsoy'un (2000, ss. 71-78) "Belediyelerde imar dosyalarının belge profili ve arşivlerinin oluşumu: Kartal Belediyesi örneği” başlıklı makalesi, hem kullanılan metot, hem de bir vaka incelemesi olması bakımından hâlâ güncelliğini koruyan bir çalışmadır.

Kurumsal bilgi kaynağı belgelerin yönetilebilmesi için gerekli bir araç olan dosya planları, dışarıdan hizmet alımı yoluyla veya kurumların kendi uzman personeli tarafından hazırlanabildiği gibi idari bakımdan bağlı olduğu üst kurum ya da meslek örgütleri tarafından da geliştirilebilmektedir. Örneğin İngiltere'de belediyelerin kullanabileceği dosya planı, Belge Yönetimi Derneği (Records Management Society) içerisinde oluşturulan yerel yönetimlerle ilgili özel bir çalışma grubu (local government group) tarafından hazırlanmıştır (Local, 2007). Planı hazırlayan grup üyelerini yerel yönetimlerde çalışan belge yöneticilerinin oluşturduğunu görüyoruz. Türkiye'de ise bu işi, meslek örgütleri yerine çeşitli projeler kapsamında belediyelerin kendileri yanı sıra Devlet Arşivleri Genel Müdürlüğü başta olmak üzere İçişleri Bakanlığına bağlı Mahalli İdareler Genel Müdürlüğünün üstlendiğini görmekteyiz. Mahalli İdareler Genel Müdürlüğünün yerel yönetimler için geliştirdiği SDP bunun açık örneğidir.

IBB'de SDP'den önce yapılan belge yönetimi çalışmalarından biri 2000 'li yıllara rastlamaktadır. Bir yıllık bir projenin ardından belediye birimlerinde uygulanmak üzere dosya tasnif planı geliştirilmiş, çalışma yönergesi hazırlanarak uygulanmıştır (IBBB, 2001). Daha sonra İBB'nin yapmış olduğu ihalelerden Arşiv Müdürlüğünün belge yönetimi ve arşiv düzenleme işleri için "Belge tarama ve indeksleme" adıyla hizmet alımı gerçekleştirdiğini öğreniyoruz (IBB, 2006). İçişleri Bakanlığının Özel İdareler ve Belediyelerde 09 Nisan 2007 tarihinden itibaren SDP uygulamalarına geçileceğini bildirmesinin ardından (İçişleri, 2007), "Dosya veya evrak niteleme, belge tarama ve indeksleme" konulu yeni bir hizmet alımının gerçekleştirilmiş olduğunu görüyoruz (IBB, 2007b).

SDP'nin kurumlarda uygulanmasıyla ilgili çalışmalara rastlamamıza rağmen akademik incelemelerin henüz yeterli düzeyde olmadığı görülmektedir. Planın 2005 yılında çıktığı, kurumlardaki uygulamasının ise bir iki yılı geçmediği göz önünde bulundurulursa, SDP konusundaki bilimsel çalışmalar bir yana, planın uygulama sonuçlarını 
dahi görmenin erken olduğu düşünülebilir. Ancak, bir genelgeyle mükelleflere duyurulan bu planın uygulama zorunluluğu bulunduğundan, kurumların bir an önce uygulamaya başlamaları beklenmektedir. Bu durum, standart dosya planını açıklayan yazılar yanı sıra kurumlarda yapılan uygulamaları anlatan çalışmalar ile çeşitli araştırma ve inceleme eserinin çıkabileceğine işaret etmektedir. Bunun bir örneğini Servet Saraç tarafından kaleme alınan standart dosya planıyla ilgili yazı oluşturmaktadır (2007a, ss. 44-46). Planın tanıtım ve değerlendirmesi niteliğinde olsa da literatüre girmiş olması bakımından dikkat çeken bir yazıdır. Çok yakın zamanda Türkiye Kızılay Derneğinde yapılan SDP uygulamasıyla ilgili bir çalışmanın sonuçları bir bildiriyle bilim dünyasına duyurulmuştur (Külcü, 2007, ss. 245-251). Planın kamu yararına çalışan bir dernekte uygulanmasını anlatan bu yazı, uygulama sonuçlarını duyurması bakımından dikkate değerdir. Buna benzer yayınlar, belge yönetimi, kurumsal bilgi yönetimi ve arşivcilik gibi sahalarla ilgilenen uzmanların bu konuya kayıtsız kalmayıp, yakın ilgi duyacakları kanaatini uyandırmaktadır.

En başta kaynak taraması ve var olan arşiv çalışmalarının incelenmesiyle başlayan bu araştırma, İstanbul Büyük Şehir Belediyesinde yapılan Standart Dosya Planı uygulamalarına dayanmaktadır. Teşkilat yapısının büyüklüğü ve fonksiyonlarının çokluğu aynı zamanda planın aktif olarak uygulanmaya başlanmasından dolayı IBB saha çalışmasında örnek olarak seçilmiştir. Planın yürütülmesiyle ilgili olarak olumlu ve olumsuz yönler her kurumda farklı şekillerde ortaya çıkabilir. Bütün bu uygulamaların sonuçlarını değerlendirmek, büyük bir ekip çalışmasını gerektireceği için bu inceleme İstanbul Büyük Şehir Belediyesindeki çalışmalarla sınırlandııımışıı. Bütünün içerisinden bir örnekleme olarak görülebilecek bu çalışma, SDP'nin uygulanması konusunda diğer belediyelere de ışık tutabilir.

$\mathrm{Bu}$ araştırmada kaynakların incelenmesi, gözlem ve görüşme başlıca veri toplama yöntemi olarak belirlenmiş̧ir. Literatür taraması sonucunda elde edilen kaynakların analiz ve değerlendirmesi yanında

* IBB Arşiv Müdürlüğü Uzmanı Nihat KARADUMAN ve Orhan GÜLTEKIN ile Yapı Kredi Kültür Sanat A.Ş. Arşiv Uzmanı Yaşar KAYA'ya verdikleri bilgilerden dolayı teşekkür borçluyuz. Ayrıca, bu çalışmaya görüşmelere katılarak katkıda bulunan diğer çalışanlara yapılacak teşekkür, yerine getirilmesi geren bir görevdir. 
saha çalışması sırasında derlenen veriler kullanılmıştır. İBB'de SDP konusunda çalışma yapan uzmanlar yanı sıra uygulamaları denetleyecek kurum arşivcileriyle de görüşülmüştür. Ayrıca, farklı belediyelerde SDP çalışması yapan arşivcilerin görüşlerine de başvurulmuştur.

Verilerin toplanması sırasında belirlenen soru ve problemler, "görüşme soruları" olarak hazırlanmıştır (Bkz. Ek 2). Bu sorular, hem büro çalışanlarına hem de uygulamaları takip eden uzmanlara sorulmuştur. Alınan cevaplardan planla ilgili yaşanan güçlükler belirlenmeye çalışılmış; üretilen çözüm yolları değerlendirilmiştir.

\section{Standart Dosya Planı ve Belediyelerin Esas Hizmetleri}

\section{Standart Dosya Planı}

Standart dosya planı, belgelerin standart konu başlığı ile kodlar altında dosyalarda düzenlenip tasnif edilmesini ve tekrar erişimini sağlayacak uygulama olarak tasarlanmış bir sınıflandırma şemasıdır. Bu planın uygulanmasıyla Bilgi Edinme Kanunu yanı sıra özellikle E-Devlet uygulamalarına geçiş için gerekli koşulların sağlanması ve temel alt yapının oluşmasının amaçlandığı anlaşılmaktadır. Devlet Arşivleri Genel Müdürlüğünün çıkarmış olduğu bir yayında (Dosyalama, 2006, ss. 4-5) SDP'nın hazırlanma gerekçesi şu şekilde açıklanmaktadır:

E-Türkiye projesi kapsamında oluşturulan çalışma gruplarından biri olan ve koordinesini Devlet Arşivleri Genel Müdürlüğünün yürüttüğü "Dijital Arşivleme ve Depolama Çalışma Grubu"nun e-belge oluşumuna alt yapı oluşturmak suretiyle elektronik ortamlarda belgelerin belirli standartlar doğrultusunda saklanmasını sağlamak; kâğıt ortamda teşekkül eden belgelerin de aynı usul ve esaslar doğrultusunda dosyalanmasını temin etmek üzere standart bir dosya planı hazırlanması kararına varımış ve bir çalışma başlatılmıştır.

Plan genel olarak iki temel kısımdan meydana gelmektedir. Bunlar "Ortak Alanlara Iliş̧kin Başlıklar" ile "Ana Hizmet Alanlarına Ait Başlıklar"dır. Bu başlıklar, onlu sınılandırma sistemine benzer bir 
yaklaşımla, "000" dan "999" kadar sıralanan ve tamamen rakamlardan oluşan kod aralığında ana ve alt konu başlıkları şeklinde yapılandırımış ve kodlanmıştır.

Ortak alanlara ait başlıklar ve onları ifade eden kodlar, Devlet Arşivler Genel Müdürlüğü tarafından önceden hazırlanmıştır. Bütün organizasyonlarda adeta kurumsal varlığın bir gereği olan personel, mali ve idari işler, yönetim ve denetim gibi hizmetler doğal olarak var olduğundan, bunlara ait fonksiyon ve faaliyetler planda ortak alanlar biçiminde ele alınmıştır. Planın uygulandığı her organizasyonda bu hizmetlerin aynı konu başlığı ve kodu ile standart biçimde ifade edilmeleri hedeflenmiştir. Bu hizmetlere ait konu başlıkları, "000"dan "099"a ve "600"den “999"a kadar olan sayı aralıklarında kodlanmışır.

Ana hizmet faaliyetlerine ait konu başlıkları ise her kurumun kendi esas fonksiyonları göz önünde bulundurularak belirlenecek ana ve alt konu başı|klarından meydana gelmektedir. Planın 100-599 kod aralığında yer alan bu başlıkları planı uygulayan her kurum kendisi belirleyecektir. Diğer bir ifadeyle, standart dosya planını uygulamak isteyen kurumlar, kuruluş amaçları doğrultusunda yürütülen faaliyetlere ait konu başlıklarını, planın yapısını bozmadan yardımcı hizmetler yani ortak alanlardan ayrı olarak kendileri geliştireceklerdir. Böylece ana hizmet faaliyetleri ile önceden hazırlanmış ortak hizmetlerle ilgili faaliyetler bir arada ve bütün olarak SDP'yi oluşturacaklardır. Plan, bu bütünlük sağlandıktan sonra kullanılacaktır.

Burada mükelleflere düşen en önemli görev, belirtilen kod aralığında kendi esas fonksiyonlarına ilişkin ana ve alt konu başlıklarını geliştirmektir. Danışma-denetim ile yardımcı hizmetlere ait başlıklar her kurumda aynı kalırken, ana hizmetler her kurumun kendi fonksiyonlarına göre değişeceğinden farklı konu başlıklarından oluşacaktır.

Tablo 1. SDP Konu Başlığı Alanları

\begin{tabular}{|l|l|}
\hline $000-099$ & GENEL KONULAR \\
\hline $100-599$ & ANA HIZMET FAALIYETLERI \\
\hline $600-699$ & DANIŞMA-DENETIMLE ILGILI FAALIYETLER \\
\hline $700-999$ & YARDIMCI HIZMETTLERLE ILGILI FAALIYETLER \\
\hline
\end{tabular}




\section{Belediyelerin Ana Hizmet Alanları}

Belediye hizmetleri, çevre temizlik ve korumasından imar ve inşaat işlerine, sosyal ve kültürel işlerden ulaşım ve alt yapı çalışmalarına kadar çok çeşitli fonksiyonları kapsar. Bu fonksiyonlar, dosyalama planında belediyenin ana hizmet alanlarını oluşturur.

Dosya planının mevcut yapısına göre belediyelerin ana hizmet alanları, 100 ile 599 kod aralı̆ıında yer alacaktır. Ancak, belediye hizmetlerine ait konu başılıkları, Içişleri Bakanlığı Mahalli İdareler Genel Müdürlüğü tarafından 250-349 kod aralığında önceden belirlendiği için daha geniş bir alan yerine dar sınırlar içerisinde hareket etme zorunluluğu oraya çıkmıştır (IBBB, 2007a).

Belediyeler ve üniversitelerin dosya planlarının hazırlanma usulü, dosya planı genelgesinde ayrıca belirtilerek, belediyelerin ve diğer yerel yönetim kurumlarının ana hizmetleriyle ilgili bir tasnif planının Içişleri Bakanlığı tarafından geliştirileceği öngörülmüştür. Genelgeye göre belediyeler ve özel idarelerin ana hizmetlerine yönelik dosya planları, İçişleri Bakanlığınca en kısa sürede hazırlanarak Başbakanlık Devlet Arşivleri Genel Müdürlüğüne gönderilecek, onaylanmasını müteakip ortak alanlarla birlikte tüm belediye, birlik ve özel idarelerde kullanılmaya başlanacaktır (Standart, 2005). Genelgeyle bildirilen bu talimat sonucunda İçişleri Bakanlığı kendi merkez ve taşra birimleri yanı sıra mahalli idarelerin de uygulayacağı bir plan hazırlamıştır. Bakanlığın dosya planı, Bilgi İşlem Daire Başkanlığının koordinesinde oluşturulurken "il özel idareleri" ve "belediyeleri" içine alan mahalli idarelerle ilgili konu başlıkları ise Mahalli İdareler Genel Müdürlüğü tarafından geliştirilmiştir (İçişleri, 2007). Ancak, ilgililerle yapılan görüşmede, genelgede belirtilmiş olmasına rağmen müdürlüğün böyle bir çalışmaya başladığı bilgisinin dışında, planın son haliyle ilgili olarak Devlet Arşivleri Genel Müdürlüğünün görüşüne başvurulmadığı ifade edilmiştir (Saraç, 2007b).

Belediyeler yanı sıra İçişleri Bakanlığının fonksiyonlarını içeren ana hizmet alanlarıyla ilgili başılıklar şu şekilde belirlenmiştir. 
Tablo 2. SDP'de İçişleri Bakanlığı Ana Faaliyet Alanları

\begin{tabular}{|l|l|}
\hline $100-149$ & Nüfus ve Vatandaşılı İşleri \\
\hline $150-249$ & Iller İdaresi İşleri \\
\hline $250-349$ & Mahalli İdareler İşleri \\
\hline $350-449$ & Sivil Savunma Hizmetleri \\
\hline $450-469$ & Kihbi İşleri \\
\hline $470-489$ & Dernek İşleri \\
\hline $490-529$ & Valilik ve Kaymakamlık İşleri \\
\hline $530-549$ & Güvenlik Iş̧leri \\
\hline
\end{tabular}

Burada Bakanlığın merkez ve taşra teşkilatı ile bağılı kurumların da verildiğini görüyoruz. Bakanlığın geliştirmiş olduğu bu plana göre "Belediye" ve "il Özel İdare" faaliyetlerine ilişkin konu grupları, 250-349 kod aralığında yer alan "Mahalli İdare İşleri"nde düzenlenmiştir (İçişleri, 2007). Belediyeler, II Özel İdareleri ve Birliklerin ana fonksiyonlarını ifade eden başlıklar, ekte verilen tablodan görülebilir (Bkz. Ek 1)

\section{Standart Dosya Planı Uygulamalarında Karşılaşılan Güçlükler}

Makalenin esas bölümünü oluşturan bu kısımda Belediyelerde yürütülen standart dosya planı uygulamalarında karşılaşılan güçlükler, İstanbul Büyükşehir Belediyesinde yapılan saha çalışması ışığında ele alınmıştır. Yerinde yapılan inceleme, gözlem ve görüşmeler sonucunda ortaya çıkan bu güçlükler ile düşünülen çözüm yolları, sekiz başlık altında toplanmiştır.

\section{Belediye Fonksiyonlarının Tespiti ve Belge Yönetimi}

Her ne kadar belediye hizmetlerine ait konu başlıkları önceden belirlenmişse de bu tespitin hangi çalışma yöntemi doğrultusunda ve ne tür koşullarda yapıldığını tam bilemiyoruz. Diğer bir ifadeyle, bir organizasyonda dosya tasnif planı oluşturulurken ana hizmetlerin belirlenip fonksiyona bağlı konu başlıklarının oluşturulması, belge yönetimi anlayışı çerçevesinde yapılacak bir dizi ön çalışmayla mümkündür. Yürütülecek bu çalışma ise belgelerin üretilmesinden ayıklama ve imhasına kadar tüm yaşam döngüsünü içine alacak şekilde düşünülüp, belge yönetimi ve arşiv disiplininin öngördüğü bilimsel 
uygulamalar ışığında gerçekleştirilecek bir proje kapsamında yapılmalıdır.

$\mathrm{Bu}$ projenin belediyelerde gerçekleştirilmesiyle ilgili olarak farklı alternatifler geliştirmek mümkün gözükse de karar mekanizmalarının önünde ilk hamlede iki seçenek durmaktadır. Bunlardan ilki, kendi personeline bu konuda eğitim aldırtıp, onlar vasıtasıyla projenin gerçekleştirilmesinin sağlanması; ikincisi ise dışarıdan profesyonel destek alınmasıdır. Örneğin İBB'nin hizmetlerinden takip edilebildiği kadarıyla dosya planı çalışmalarının profesyonel destek satın alınarak gerçekleştirildiği anlaşılmaktadır (IBB, 2007b).

Bu çözüm yollarının hangisi uygulanırsa uygulansın, ana hizmet alanlarıyla ilgili kısmın ortaya çıkarımasında, belgelerin üretilmesinden ayıklama ve imhasına kadar tüm yaşam döngüsünü içine alan "belge yönetimi programı" kapsamında bir dizi iş süreci adımının takip edilmesi gerekir. Bu adımları, problemin tespiti ve projelendirme, çalışma planı, verilerin toplanması ve analiz, taslak planın geliştirilmesi, görüş ve değerlendirmelerin alınması, uygulama el kitabının hazırlanması, eğitim ve kontrol biçiminde sıralamak mümkündür (Çiçek, 2007, ss. 237-238). Bir kurumda işlevselliği olan uygulanabilir bir dosya planı hazırlayabilmek için belirtilen süreç adımlarının titizlikle takip edilmesi gerekmektedir.

Başarıı bir dosya planı yapabilmek için belirtilen bu süreç takip edilirken bir takım öncelikler bulunmaktadır. Bu önceliklerin, yürütülen projeler sonucunda ortaya çıkan ve adeta bu konuda çalışma yapan uzmanların ortak bir kanaati olduğu görülmektedir. Bu önceliklerden ilki projeye olan inanç ve destektir. Örneğin belediyelerde uygulanan bir projede özellikle Belediye Başkanı gibi ilgili karar mekanizmasının tam desteğinin alınması gerekir. Proje bütçesinin oluşturulup gerekli kaynakların temini de sonuca ulaşmada önemli bir araçtır.

Tüm bunların yanında esas kilit noktayı ise planı uygulayacak personel oluşturmaktadır. Sistemin işlemesi için personelin sisteme güvenmesi gerekir. Uygulamada sürekliliğin sağlanması, planı kabul edip benimsemek kadar uygulamada gösterilecek kararlılıkla mümkündür. Bu yüzden iyi bir plan yapmak önemlidir; ancak, bu planın 
uygulanmasını sağlamak daha da önemlidir. Verilecek uygulama eğitimiyle desteklenen personelin kurulacak programa olan inancı, istenen başarının elde edilmesinde öncelikli sırayı teşkil etmektedir. Aksi halde, emek verilerek hazırlanan planın uygulanmaması gibi ciddi bir problemle karşı karşıya kalınabilir.

\section{Fonksiyonların Karmaşıklığı}

Bir dosya tasnif planında yer alan ana ve alt konu başlıkları şemasının, ait olduğu kurumun fonksiyonlarına göre oluşturulması gerektiği hem uygulamacılar hem de teorisyenler tarafindan kabul gören bir anlayıştır. Bu yüzden organizasyonların yerine getirmeleri gereken işleri tanımlayan fonksiyonlar, mantıklı bir dosyalama ve sınıflandırmanın temelini oluşturur (Çiçek, 2007, s. 238).

DSP'deki ana ve alt konu başlıklarının, kurumların faaliyetleri ışı̆̆ında yapılandırıldığı ifade edilmektedir (Standart, 2005). Ancak, uygulama yapan uzmanlarla yapılan görüşmede (Karaduman, 2007) genel düşünce, planda faaliyetten daha çok hizmet birimlerinin esas alındığı ve belgelerin konularının ön plana çıkarıldığı yönündedir.

Özellikle belediye gibi teşkilat yapısı ve birimlerin sorumlulukları siyasi oluşuma göre değişebilen kurumlarda, birimlerden hareketle oluşturulacak bir planın kısa vadede kullanılabilir gözükmesine rağmen ileriki dönemlerde sorun çıkarması kaçınılmazdır. Yeni kurulacak birimler veya yeni gelişmelere göre ismi değiştirilen bürolar, dosya planında doğrudan yer bulamayacaktır. Bu olumsuzluk, bir belediyede zaman içerisinde karşılaşlabilecek bir durum olarak görülebilir. Ancak, planın tüm belediyeleri kapsayacak şekilde geliştirildiği düşünülürse, diğerlerinde de benzer sıkıntılar yaşanabileceği uzak bir intimal değildir. Çünkü her belediyede faaliyetlerin yürütücüsü birimlere ve bürolara, standart adlar verilmemektedir. Aynı işi yapan büroların belediyelerde farklı isimler aldığı görülmektedir. Bu sebeple çoğu belediye kendi kullandığı başığı planda göremediği için onu kullanmakta zorlanacaktır.

Dosya planının fonksiyon odaklı olması gerektiği kabul edilse de bunu gerçekleştirmenin kolay olmadığı bilinmelidir. Açılan-kapanan, birleşen ve ayrılan birimlerin yürüttüğü fonksiyonlar, geçici olarak 
yürütülen işler, fonksiyonun aynı birimde başlayıp orada bitmemesi, aynı faaliyet olmasına rağmen birimlerde farklı isimlerle kullanılması, çalışanların fonksiyonu açıklamada yetersiz kalmaları gibi durumlar, dosya planında konu başlıklarını oluşturacak fonksiyonların tespitini zorlaştırmaktadır. Bu yüzden birçok kurumda olduğu gibi belediyelerde de fonksiyonların ortaya çıkarılması karmaşık bir işlemdir.

$\mathrm{Bu}$ karmaşıklığı çözümleyebilmek ise birimlerde yapılacak iyi bir fonksiyon envanter çalışmasıyla mümkün olabilir. Bu çalışmada fonksiyonların iş süreci adımları takip edilip, bu adımların bir sistem analisti titizliğinde değerlendirilmesi gerekir. Böylece SDP'de geçen konu başıklarının bir kısmı yeniden tasarlanacak, olmayan başlıklar da eklenecektir.

\section{Elektronik Belgelerin Düzenlenmesi}

Bürolarda dosya planı geliştirilirken kâğıt evrak kadar elektronik belgeler de göz önünde bulundurulmalıdır. Kâğıt gibi elektronik belgeler de kurumun fonksiyonlarının yürütülmesi sırasında üretildiğinden, her iki taşıyıcı ortam, bürokratik uygulamalar itibariyle aynı işleve sahiptir. Dolayısıyla belge yönetimi uygulamaları da birlikte gerçekleştirilmelidir.

Bir dosya tasnif planı bulunmayan organizasyonlarda elektronik belgenin yönetim ve kontrolü oldukça güçtür. Yapılan çalışmalar bu düşüncenin hakıılığını ortaya koymaktadır. Dosya adlarını gösterecek standart bir liste olmaması sebebiyle belgeler bir klasör yerine birçok klasörde kopyalanarak dosyalanmaktadır. Büro çalışanları zaman zaman elektronik ortamdaki belgeleri de aramak zorunda kalabilmektedir. Bir dosya planı bulunmaması sebebiyle bilgisayar ortamında geleneksel usullerle yapılan dosyalamada, belgeler tekrar erişimi mümkün olmayacak şekilde muhafaza edilmektedir (Parker, 1999, s. 22).

Durum böyle olunca elektronik belge yönetimi konusunda çalışma yapan uzmanlar, bu belgeler için de dosya tasnif planının gerekli olduğunu ifade etmişlerdir. 
SK1.1.1 EBYS (Elektronik Belge Yönetimi Sistemi) ait olduğu kurumun yapısını ve fonksiyonlarını yansıtacak bir dosya tasnif planını içinde barındırmalı ve / veya kurum dosya planı ile uyumlu olmalıdır (Kandur, 2006, s. 15).

Burada savunulan görüş, elektronik evraklarla ilgili tasnif planının kurumun fonksiyonlarından bağımsız değil, aksine kâğıt evrakta olduğu gibi kurumsal yapıyı ve fonksiyonları ortaya koyacak şekilde oluşturulması gerektiğidir. Kâğıt belgeler için öngörülen fonksiyonel anlayış ve tasnif metodu aynı şekilde elektronik belgeler için de düşünülmelidir. Belediyede ilçelere ve mahallelere göre ya da ada, pafta ve parsel numaralarına göre yapılan bir düzenleme ne ise elektronik belgeler için de aynı mantık geçerlidir (Stewart, 2002, s. 108). Elektronik belgelerin yönetilmesi sırasında da aynı dosya planı uygulanmalı ve uyumlu çalışması sağlanmalıdır. Dolayısıyla kurumlar kendi ana faaliyetleriyle alâkalı plan geliştirirken, mutlaka elektronik ortamda üretilecek dokümanlar göz önünde bulundurulmalıdır.

Çünkü gelişmiş ve gelişmekte olan ülkelerde olduğu gibi Türkiye'deki kurumlar da teknolojik gelişmelerin sunduğu imkânlardan hızlı bir şekilde yararlanmaktadır. İB gibi daha birçok kurum elektronik belge yönetimi programlarını oluşturma yolundadır.

İBB'de elektronik belge yönetimiyle ilgili bir proje yürütülmektedir. $\mathrm{Bu}$ yüzden belediyedeki SDP çalş̧maları, elektronik belgeleri de kapsamaktadır. Yazılım ve gerekli diğer alt yapı çalışmaları hazırlanan projenin 2008 yılı içerisinde sonuçlandırıması planlanmaktadır. Böylece belediyede hem elektronik imza, hem de elektronik belge yönetimi uygulamasına geçilecektir (Gültekin, 2007). Proje kapsamında SDP'nin elektronik belgeler için de uygulanmaya çalışıldığı bildirilmiştir. Ancak, henüz test aşamasında olduğundan sonuçlarını değerlendirmek şimdilik mümkün olamamıştır.

Belgelerin elektronik ortamda kontrol ve yönetilmesiyle ilgili olarak her kurum kendi çabasıyla bir sitem geliştirmeye çalışı̆ğı için birbirinden farklı uygulamalarla karşılaşma intimali yüksektir. Bu durumun, kurumlardaki dosyalama işlemlerinde tek tipliliğin sağlanması amacıyla geliştirilen SDP'yi standart olmaktan uzaklaştıracağı düşünülmektedir. 
Bu yüzden her ne kadar planın elektronik belgelerin dosyalama işini de kapsayacak şekilde geliştirildiği ifade edilse de uygulamada bunun nasıl gerçekleştirileceğinin örneklerle açıklanmaya ihtiyacı olduğu görülmektedir.

\section{Önceki Dosya Planlarıyla Standart Dosya Planının İlişkisi}

Dosya planları geliştirilirken önceden uygulanan bir dosya tasnif planı var ise oradaki konu başlı̆ı ve kodları da dikkatle incelenmelidir. Çünkü kurumda bulunan dosya ve seriler, daha önce kullanılan plana göre tanımlanmış olabilir. Bu yüzden önceki kod ve başlıkların yeni planla ilişkilendirilmesi gerekir. Serilerde bütünlüğün sağlanabilmesi için güncelliğini kaybetmiş dahi olsa eski plan göz ardı edilmemelidir.

Aynı fonksiyon kapsamında üretilmiş güncel olmayan dosyalar ile yeni sisteme göre üretilecekler arasında mutlaka organik ilişki kurulmalı; bu ilişki, çeşitli göndermelerle yeni planda gösterilmelidir.

Farklı nedenlerden dolayı bir fonksiyona ait işlemler zaman içerisinde değişebilmektedir. Fonksiyonla beraber üretilen belge ve dosyalar da hem genel belge profili bakımından hem de dosya adı itibariyle değişiklik gösterebilir. Bu değişikliğe bağlı olarak da belgeler farklı adlar altında işlem görmüş ve dosyalanmış olabilir. Değişim her ne şekilde olursa olsun, bürolarda ve birim arşivlerinde bulunan dosyalar için devamı ve düzenli seriler oluşturmak esastır. Serilerdeki bu devamlılığın sağlanabilmesi için yeni dosya planında önceki dosya ve serilerle yenileri arasındaki ilişkinin bir şekilde açıklanması gerekmektedir. Bu durum SDP'de bir açıklama notuyla gösterilebilir.

Bu açıklama notu, hem güncel hem de güncel olmayan safhada kullanışı veriler sunar. Büro çalışanları ve karar mekanizmaları, bir fonksiyonun ne zaman başlayıp nasıl yürütüldüğünü, zaman içerisinde geçirdiği değişim ve dönüşümleri, bu açıklamayla takip edebilir. Belgeler arşiv malzemesi olduğunda dosya planındaki bu bilgi, aynı fonksiyon kapsamında üretilen, ancak zamanla farklı isimler alan dosya ve serilerin tek başlık altında toplanmalarına yardımcı olacaktır. Serilerde devamlıı̆ın gösterilmesi, özellikle niteleme ve düzenleme çalışmalarında arşivcilere de büyük kolaylık sağlayacaktır. 
SDP'de bu konunun yeteri kadar ele alınmadığı görülmüştür. Oysa önceki dosya planına ait kodlar planda bir şekilde gösterilmeliydi. Bunun yeri ise plandaki tabloda ayrılacak "notlar" başlıklı bir alan olabilir. Planda seriye verilen dosya adı ve kodu bulunurken aynı satırda bu serinin daha önce almış olduğu dosya adı ve kodu belirtilir. Böylece kullanıcılara serinin öncesi hakkında bilgi verilerek, seride eski ile yeni düzen arasındaki bütünlük sağlanmış olacaktır.

Bu durum İBB'de daha bir ön plana çıkmaktadır. Bunun sebebi ise kurumda SDP'den önce de bir dosya planının uygulanıyor olmasıdır. Dolayısıyla evrak ve dosyalara, bir dosya kodu verilmekteydi. Ancak, yeni planla birlikte bunlar değişmiştir. Örneğin önceki dosya planında "katı atık toplama hizmetlerine" "220.100" kodu verilirken (IBB, 2001) SDP'de katı atık toplama işlemleri "312 02" koduyla ifade edilmektedir (IBB, 2007). Katı atık toplamayla ilgili önceki dosyalarla yeniler arasında bir organik bağın kurulması gerekir.

Bu bağın açıklanması ise yeni planda verilecek bilgi notuyla mümkün olabilir. Böylece aynı fonksiyon ve ona ait dosya serisi zaman içerisinde farklı dosya ad ve koduyla tanımlansa dahi yeni planda gösterilecek bu ilişki, serilerde geriye dönük olarak bütünlüğün sağlanmasına yardımcı olacaktır.

\section{Kuruma Gelen Yazıların Durumu}

Dosyalama planıyla ilgili ele alınması gereken konulardan biri de kuruma gelen yazılara kod numarası verilip verilmeyeceği meselesidir. Bir yazı üretildiği kurumda ait olduğu konuya göre dosya planından numara alırken, dışarıdan gelen yazılara kendi dosyalama planına göre kod numarası mı verilmeli, yoksa bir numara verilmeden mi kullanılmalıdır.

Bu soruya kısmen cevap olabilecek bir açıklama, Devlet Arşivleri Genel Müdürlüğü'nün çıkardığı Dosyalama ve Standart Dosya Planı adlı kitapta "dosyalama işlemlerinde uyulacak kurallar" ortaya konurken şu şekilde verilmiştir.

"Bu tanım yalın ifade ile birimimize gelen veya birimimizden çıkan yazıların konulacağı dosyanın (adresinin) belirlenmesi ve belirlenen 
adres doğrultusunda çeşitli tekniklerle dosyalarına konulması işlemidir, diyebiliriz" (Dosyalama, 2006, s. 54).

Bu açıklama ışığında dışarıdan kuruma gelen belgeler konu veya vaka ilişkisine göre giden yazılarla birlikte aynı dosyada yer almalıdır. Fakat, aynı dosyaya konan gelen yazılara kurumun kendi dosya planına göre kod numarası verilip verilmeyeceği hususu yeteri kadar açıkığa kavuşturulmamıştır. Planda yapılan diğer bir açıklamaya göre dışarıdan gelen ve planda ortak alanlar olarak belirlenen konu başlıklarında yer alan evraklar, zaten her kurumda aynı kodu alacağı veya alması gerektiği için teorik olarak ciddi bir problem teşkil etmeyecek gibi gözükmektedir (Dosyalama, 2006, s. 68). Ancak, özellikle kurumun ana hizmet alanıyla ilgi olan belgeler, geldiği yerin dosyalama planına nasıl entegre edilecektir. İşlemi bittikten sonra herhangi bir kod vermeden ait olduğu konuya göre dosyasına kaldırmak yeterli midir? Bu belirsizliği ortadan kaldırmak için özellikle gelen evraklarla ilgili dosyalama hizmetinde işlemlerin nasıl yürütüleceği konusunun açıklığa kavuşturulması gerektiği anlaşılmaktadır.

Daha önce çeşitli kurumlarda yürütülen evrak yönetimi programlarına bakıldığında, giden yazılarda olduğu gibi gelen yazılara da mutlaka kendi dosyalama planına göre kod numarasının verildiğini görüyoruz. Kuruma gelen belgeler her hangi bir dosya numarası almamışsa ya da daha önce gönderen kurum tarafından verilen dosya numarası geldiği kurumun dosya planına uygun değilse, belgenin fonksiyon ve konusu göz önünde bulundurularak, görevli memur tarafından kendi dosyalama planına göre bir dosya kodu verilir. İstanbul Büyükşehir Belediyesi'nin 2000 yılı başı itibariyle hazırlayıp yürürlüğe koyduğu “Dosya Tasnif Planı Uygulama Yönergesi”nde kurum dışından gelen belgelerin dosyalama planına göre konu kodu aldıktan sonra dosyasına kaldırııması gerektiği belirtilmiştir (IBB, 2001, s. 12).

Daha önce de ifade edildiği gibi Standart Dosyalama Planı'nın genel mantığına göre zaten ister içeride üretilsin isterse dışarıdan gelsin kurumda kullanılan her türlü belge, mutlaka dosyalanmalıdır. Dosyalama işlemi bu plana göre yapılacaksa, doğal olarak gelen ve giden her evrakın bir dosya kodu alması ve belgenin türü ne olursa olsun ait olduğu dosyasına kaldırıması gerekmektedir. Bu anlayıştan dolayı 
kurumda üretilenlere kod verilmesi, gelenlere verilmemesi gibi bir durum uygulanabilir gözükmemektedir.

Dosyalama anlayışı yanı sıra dosyadaki belgelerin bütünlüğünün korunması için de bu durum gerekli bir uygulama olarak karşımıza çıkmaktadır. Özellikle bürolarda dosyasından çıkarılarak kullanıımak istenen bir belgenin tekrar ait olduğu dosyasının bulup konulması, önceden dosya kodunun verilmesiyle mümkün olabilir. Böylece evrak kayıpları da önlenecektir. Güncel evraklar için olduğu kadar arşive devredilmiş olanlar için de durum pek farklı değildir. Örneğin arşive devredilmiş bir belge, doğru bir uygulama olmamasına rağmen bazen dosyasıyla değil, dosyasından çıkartılarak kullanılmaktadır. Belge arşive geri döndüğünde ait olduğu dosyayı belirleyen temel öğe önceden verilmiş bu dosya kodu olacaktır. Dosyasından çıkarılarak kullanılmak istenen belgenin işlemi bittikten sonra konulacağı yer konusunda bir tereddüt yaşanmayacaktır. Bu durumda bir kuruma gelen ya da kurumdan giden her türlü evrakın nasıl ki evrak kayıt numarası alması gerekiyorsa, aynı şekilde dosya kodu alması da zorunluluk olmalıdır. Çünkü bir evraka dosya kodu vermeden her hangi bir dosyaya kaldırmak, evrakın ait olduğu fonksiyonla olan ilişkisini kurmadan kullanmak demektir. Bu durum, dosya bütünlügünün tehlikeye girmesine sebep olabilir. Dolayısıyla dosya planı kullanılan bir organizasyonda gelen ve giden her türlü evraka kod numarası verilmesi bir zorunluluktur.

Dosya, belgeleri fiziksel olarak bir arada tutarken, dosya kodu belgeler arasındaki organik bağı kurar. Diğer bir deyişle, ister kurum üretsin isterse dışarıdan kuruma gelsin aynı fonksiyon kapsamında kullanılan dokümanların ait oldukları fonksiyonla, dosya ve seriyle, aynı zamanda birbirleriyle olan ilişkileri bu kodla kurulmuş olur. Bu ilişkinin ne kadar gerekli olduğu güncel evraklar kadar arşivlik malzeme için de düşünülürse, uygulamanın önemi daha iyi anlaşılır.

\section{Dosyalama Anlayışındaki Belirsizlik}

Kurumların dosyalama anlayışındaki belirsizlik iki yönden ele alınabilir. Bunlardan ilki kurumda yürütülen dosyalama işlemlerinin olması gereken vaka, konu, gölge, geçici dosya vb. dosya türü anlayışından uzak yürütülmesidir. Bu olumsuzluk, dosya ve serilerin adlandırımasında ve 
yapılan envanter çalışmalarında, uzmanları yanılgıya düşürebilir. Diğeri ise geliştirilen dosya planındaki konu başlı̆̆ı ve kodlarının belirtilen dosyalama türlerine göre bir mantığa sahip olmamasıdır. Başka bir deyişle, planda verilen konu başlığının bir vaka dosyasını karşıladığı, bu yüzden türü ne olursa olsun ilgili tüm belgelerin bu dosyaya konulması gerektiği hususunun yeteri kadar açık olmamasıdır.

Çevre, alt yapı, imar ve ihale işlemleri gibi fonksiyonlara ait belgelerin çoğunlukla vaka dosyasında düzenlendiği göz önünde bulundurulursa, belediyelerde üretilen vaka dosyası oranının oldukça fazla olduğunu düşünmek çok da zor değildir. Tipik bir vaka dosyası örneği olan "imar dosyaları", belediyelerin belki de en hacimli dosya serilerinden birini oluşturmaktadır. Belediyelerdeki genel uygulama, her binaya bir imar dosyasının açıması biçimindedir. Bu dosyalarda imar durum belgesi, inşaat ruhsatı, tapu vb. birçok belge bulunmaktadır (İcimsoy, 2000, s. 51). SDP'de belediyelerdeki imar işlerine 310.01310.99 kod aralığındaki konu başıkları ayrımıştır. Bir inşaat yapımıyla ilgili faaliyetler ise bu kod aralığında "imar durum belgesinden" "projeler" ve "yapı denetimlerine" kadar birçok konu başlığını ilgilendirmektedir.

İnşaatla ilgili belgeler planda bu başılılara göre düzenlenecektir. $\mathrm{Bu}$ durumda planı uygulayanlar, belirtilen başı|klar altında ayrı ayrı dosyalar mı oluşturacaklar; yoksa bu kod ve adlar farklı olsa da bu belgeleri binaya yani vakaya ait tek bir dosyada mı muhafaza edecekler. Fonksiyonun yapısına göre binaya ait bütün belgelerin imar dosyası adıyla oluşacak vaka dosyasında bulunması gerektiği düşünülürse, kullanıcılar bu duruma nasıl karar verecek. Bu ve benzer şüpheli durumları ortadan kaldırıp kullanıcıya kolaylık sağlamak için planın ana ve alt konu başlıklarında bu sorulara cevap olabilecek bir açıklama notuna intiyaç bulunmaktadır. Planı uygulamaya çalışan uzmanların da aynı kanaati paylaşııları, yapılan görüşmeler sırasında anlaşılmışırı (Kaya 2007; Karaduman, 2007). 
Tablo 3. SDP'de Bayındırlık İmar İş ve İşlemleri Ana Konularına Ilişkin Bazı Alt Konular

\begin{tabular}{|l|l|}
\hline 310.05 & İmar Durum Belgeleri \\
\hline 310.07 & Ruhsat ve İzinler \\
\hline 310.07 .01 .02 & Verilen İnşaat Ruhsatları \\
\hline 310.08 .03 & Temel Vizesi \\
\hline 310.09 & Proje Onay İşleri \\
\hline 310.11 & Yapı Denetim İşleri \\
\hline \multicolumn{1}{|c|}{} & \\
\hline
\end{tabular}

IBB'nin daha önce uyguladığı dosya tasnif planında bu sorun, planda konu başlıklarından sonra gelen "Açıklamalar" başlığı altındaki alanda verilen notlarla giderilmeye çalışılış̧ır. İmar dosyalarıyla ilgili bilgi şu şekildedir: Planda imar konusundaki işlemler için "480.100 İmar" genel konu başığı açılıktan sonra hemen yanına "imar dosyaları" biçiminde açıklama notu düşülmüştür. Ayrıca bu genel başığın altında verilen imarla ilgili faaliyetlere ait belgelerin de imar dosyasında muhafaza edilmesi gerektiği " 450.300 İnşaat Ruhsatı"nın karşısına "Bir örneği 480.100'deki imar dosyasına konur" şeklinde verilen bir açıklamayla belirtilmiştir (IBB, 2001).

İmar dosyası gibi tipik vaka dosyası olan bir ömek de "personel özlük dosyaları"dır. SDP'de "900-929" numaralı kod aralı̆ı̆ personel işlerine ayrımıştır. Bu alanda atama işlemlerinden görevlendirmelere, sicil işlemlerinden emekliliğe kadar çeşitli konu başlıkları yer almaktadır. Planın mevcut bu yapısına göre özlük dosyaları için bir vaka dosyası yerine, oraya girmesi gereken belgelerin konusuna göre ayrı ayrı dosyalar açılması gerektiği anlaşımaktadır (Karaduman, 2007).

Oysa, hem 4857 Sayılı İş Kanunu'nun 57. maddesinde (İş Kanunu, 2003) hem de 657 Sayilı Devlet Memurları Kanunu'nun 109. maddesinde (Devlet Memurları Kanunu, 1965) personel siciliyle beraber özlük dosyasının da tutulması gerektiği açıkça ifade edilmiştir. 
Tablo 4. SDP' de Personel İşlerine Ait Ana Konulara Illişkin Bazı Alt Konular

\begin{tabular}{|l|l|}
\hline 900 & Personel İşleri \\
\hline 903.02 & Naklen Atama \\
\hline 904.01 & Kurum İçi Görevlendirme İşlemleri \\
\hline 905 & İşten Ayrılma \\
\hline$\ldots$ & $\ldots$ \\
\hline 909 & Sicil İşlemleri \\
\hline
\end{tabular}

Dolayısıyla planda diğer vaka dosyalarında olduğu gibi personel özlük dosyalarıyla ilgili de bir açıklamaya yer verilmelidir.

Standart dosya planını kullananlar için bir rehber niteliği taşıyan kaynakta (Dosyalama, 2006, s. 68) her ne kadar "şartnameler" örneği verilerek durum açıklanmaya çalışılsa da bunun yeterli olmadığı görülmektedir. Birer vaka dosyası örneği olan imar ve personel özlük dosyalarında olduğu gibi gerekli görülen her konu başlığında açıklama notu verilmelidir.

$\mathrm{Bu}$ durum, aynı zamanda tanımlayıcı başlıkların geliştirimesi gerektiğini açığa çıkarmaktadır. Başka bir deyişle, SDP'de yer alan konu başlıklarının dosya ve serileri doğrudan karşılaması gerekir. Ancak, oluşturulacak dosyaların türleri belirli değildir. Başlığı karşılayan dosyanın vaka, konu veya gölge dosya mı olduğu bilinmemektedir. Oysa birimlerin yürüttüğü fonksiyonlar incelenip analizler yapilırken, o fonksiyon kapsamında üretilecek dosyanın da niteliği belirlenmelidir. Belirlenen bu nitelik doğrultusunda planın açıklamalar kısmına fonksiyonun tanımlanması yanı sıra üretilen belgelerin ne tür dosyada tutulacağı da belirtilmelidir. Böylece planı uygulayan büro çalışanları, fonksiyonun karakteristik yapısına uygun olan dosya türünü kullanacaklardır.

\section{SDP'de Belediye Hizmetlerine Ait Konu Kod ve Başlıklarının Yetersizliği}

IBB'de standart dosya planı incelenirken bu planın ilk olmadığı, daha önceden yapılmış farklı çalışmaların da bulunduğu belirtilmişti. Bu 
konuyla ilgili olarak son on yıl içerisinde yapılmış iki ayrı çalışmanın daha olduğunu görmekteyiz. Bunlar, 2000 yllında İB'de yürütülen belge yönetimi projesi ile Devlet Arşivleri Genel Müdürlüğünün büyükşehir ve il belediye başkanlıklarının arşiv malzemesi tespitiyle ilgili yürütmüş olduğu çalışmalardır (Büyükşehir, 2005). Bu sebeple belediye hizmetlerine yönelik konu başlıkları, birkaç farklı dosya ve saklama planından karşılaştırmalı olarak ele alınabilir.

Belediye hizmetlerine ait konu başlıklarının adlandıııması ve tanımlanmasıyla ilgili olarak her üç çalışmada farklılıklar bulunduğu görülmüştür. Belediyelerdeki arşiv malzemesi tespit çalışması, her ne kadar bir dosya planı olmasa da belirlenen malzemenin tanımlanması, dosya serileri ve hacmi bakımından değerlendirilebilecek niteliktedir. Bu çalışma belediyedeki müdürlüklerde bulunan dosya ve serileri içermektedir. Çalışmada yer alan baş̧ıklar, konu başlığı niteliğinde olan bir dosya veya seri adından daha çok birimde bulunan malzemenin içeriğine ve üretildiği işe göre tanımlanmıştır. Örneğin Bayındılık Bakanlığı tarafından onaylanan plan etütleri, "Onaylı Plan Etütleri” veya "Plan Etütleri - Onaylı" biçiminde değil "İmar İdare Heyetince tasdiklenip Bayındırlık Bakanlığı'nca onanan plân etütleri” gibi bir açıklama başlı̆ı şeklinde verilmiştir (Büyükşehir, 2005). Burada belki ilk önce konu başlığı olarak dosya serisinin adı, ardından belirtilen bu açıklama verilebilirdi. Buna rağmen belediyelerde üretilen belgelerle ilgili bir fikir verip, belgelerin saklama sürelerini ifade ettiği için önemli bir başvuru kaynağıdır. Özellikle standart dosya planındaki dosya ve serilerin saklama sürelerinin belirlenmesinde kullanılabilir. Çünkü saklama süreleriyle ilgili yapılan bu tespit, her ne kadar SDP'deki başlıkları karşılamasa da Türkiye'de bu konuda en yetkin kurum olan Devlet Arşivleri Genel Müdürlüğü tarafından yapıldığından öncelikle değerlendirilmesi gereken bir çalışmadır.

Bu iki çalışma göz önünde bulundurularak, SDP'deki belediye hizmetlerine yönelik başlıklar, göndermelere duyulan intiyaç, tanımlayıcı başlık niteliği taşıyıp taşımamaları, aynı faaliyeti ifade eden birden fazla konu başıı̆ının bulunması ve yer almayan belediye hizmetleri bakımlarından ele alınabilir. 
Standart dosya planında bazı başlıklar arasında göndermelerin yapılması gerektiği anlaşılmaktadır. Bu konuda tipik bir örnek ihale işlemlerini içeren konu başıı̆ıdır. IBB Yapı İşleri Müdürlüğü bir okulun bakım onarımını ihale ile yaptıırsa, hangi kodu kullanıması gerekir (Karaduman, 2007). Planda "Emlak ve İnşaat İşleri" ana konu başlı̆ı altında geçen "755.02-Ihale İşlemleri" mi yoksa diğer bir alandaki "318.02-Okul Yapım İşleri" mi uygun olan başlıktır (IBBB 2007). Aynı şekilde yol, köprü, asfalt vb. diğer alt yapı yatıımı için de aynı soruyu sormak mümkündür. Dolayısıyla planda inşaat işleriyle ilgili fonksiyon bir başlık altında düzenlenmeli, bu konuyla alâkalı diğer başlıklara gönderme yapılmalıdır.

Bu konunun daha önceki İBB dosya tasnif planında açıklama notlarıyla çözülmeye çalışıldığını görüyoruz. Ayrıca, bütün alt yapı çalışmaları planda "400-Emlak-Inşaat" ana konu başığı altında toplandığından yatııımlarla ilgili iki ayrı konu başığı oluşmamıştır. Bununla birlikte yürütülen çalışmanın iki ayrı faaliyeti içermesi ve üretilen dosyaların idari sebeplerden dolayı farklı yerlerde oluşması durumunda, bu husus verilen notla açıklanmışıı. "460.100-Yatıım İhaleleri" konu başlı̆ı kısmında, "makine teçhizat ve taşıt alımı ile yapı tesis ve büyük onarımla alâkalı ihale dosyaları" biçiminde açıklama notunun bulunduğunu görüyoruz. Ayrıca, "Ihale ödemeleri (hakedişler) için 731.000 ve 732.000 kodlarından uygun olan kullanılacaktır" açıklaması yer almaktadır (IBB 2001). Böylece yatırım inaleleri için tek bir konu başlı̆ı kullanılmakta, bununla ilgili yapılan ödemeler ise planın "730.000-Giderler" ana başlığı kısmında "732.710-Yapı, tesis büyük onarım giderleri" alt başlı̆ı altında verilmektedir.

Bazı fonksiyonların, SDP'nin farklı alanlarında aynı veya benzer konu başlıklarıyla verildiği görülmektedir. Bunlardan biri projeler konu başlığıdır. Planda araştırma-planlama ve koordinasyon ana konu başlığı kısmında "604-Proje İşleri" yer almakta; ayrıca, dış ilişkiler ve Avrupa Birliği alanındaki ülkelerde ikili ve çok taraflı ilişkiler kısmında "724.06.02Projeler" ile aynı alanın uluslar arası ve bölgesel kuruluşlarla ilişkiler kısmında "730.06-Projeler" başlı̆ı bulunmaktadır (IBB, 2007b).

Bütçe işlemleri konusunda da benzer bir durumla karşılaşılmaktadır. Planda büţ̧e çalışmalarına iki farklı kısımda 
rastlanmaktadır: Bunlardan biri, belediyelerin ana hizmet alanlarında yer alan "255-Belediye Bütçe İş ve İşlemleri", diğeri ise yardımcı hizmet alanında bulunan "840-Mali İşler" ana konu başlığı altında verilmiş olan "841-Bütçe İşleri"dir. Bu durumda belediyenin yıllık bütçe çalışmaları ve bütçeyle ilgili diğer işlemler, 255'de mi, yoksa 841'de mi değerlendirilecektir. Diğer bir ifadeyle, bütçe çalışmaları, her kurumda olduğu gibi yardımcı hizmetlerden mali işler içerisinde mi; yoksa belediyelerin ana hizmetleri arasında yer aldığı düşünülüp, belediye bütçe iş ve işlemleri arasında mı değerlendirilmelidir. Aynı konunun bu şekilde farklı alanlarda bulunması, kurumlar hatta kurum içerisinde birimler arasında dahi farklı uygulamalara sebep olabilir.

SDP'de bir fonksiyonla ilgili farklı konu başlıkları bulunurken, bazı belediye hizmetlerinin yer almadığı görülmüştür. Bunlardan birisi İBB Harita Müdürlüğünün yürütmüş olduğu "numarataj işlemleri"dir (Karaduman, 2007). Bu adres bilgileri ve numarataj işlemleri, önceki planda "060.100-Tapu ve Kadastro Bilgileri" konu başlığında verilmişken, SDP'de yer almamaktadır. Belediyeler arşiv malzemesi tespit çalışmasında ise Harita Şube Müdürlüğü faaliyetleri arasında "Harita ve Planlar" başlığıyla gösterilmiştir (Büyükşehir, 2005). Önceki dosya planında ise "060.000-Harita" ana başlığıyla verilmiştir (IBBB, 2001).

SDP'de yeri belirlenemeyen bir konu da belediye mülklerine ilişkin işlemlerdir (Karaduman, 2007). Örneğin İBB'ye ait mülklerin sicil dosyaları, hangi konu başlığı altında yer alacaktır. İBB'nin önceki dosya planında belediye mülkleri, "400.000-Emlak ve İnşaat" ana konu başlığı altındaki "420.000-Belediye Mülkleri" alt konu başlığında verilmiştir (İBB, 2001). Ayrıca mülklerin sicil dosyalarıyla ilgili olarak "kurumun mülkiyetine ait her türlü gayrimenkulün sicil dosyaları" biçiminde bir açıklama bulunmaktadır. Açıklamalar kısmındaki bu bilgi notundan belediyenin sahip olduğu gayrimenkullerle alâkalı belgelerin belirtilen dosya kod ve adıyla açılacak vaka dosyası türünde bir sicil dosyasında tutulacağı anlaşılmaktadır.

İBB'de kullanılan daha önceki planda araçların akaryakıtlarıyla ilgili olarak "akaryakıt fişleri" adıyla bir başlık bulunmakta, kullanılan fiş dosyaları bu başlık altında seri oluşturmaktaydı (Gültekin, 2007). SDP'de doğrudan bu ad bulunmayıp "801.03 Akaryakıt İşleri” adı altında bir konu 
başlı̆ı kullanılmıştır. Bu durumda yeni bir alan mı açılmalı, yoksa bu başlık mı kullanılımalıdır. Eğer fişlerle ilgili yeni bir başlık açılacaksa, bu başlık ile daha önce kullanılan başlık ilişkilendirilmelidir. Akaryakıt fişleri serisinde devamlılığın sağlanması için bu ilişkinin gösterilmesi gerekir.

Planda yer almayan bir başka faaliyet ise IBB'nin Sağlık ve Hıfzıssıhha Müdürlüğünde üretilen çeşitli inceleme raporlarıdır. Örneğin birimde üretilen "su raporları", "gılda raporları" gibi serilere ait bir konu başlı̆ına yeni SDP'de rastlanmamıştır (Gültekin, 2007). Planda yer alan "311.11.04-Labotaruvarlar" alt konu başlığı terminoloji bakımından bu raporlarla ilişkili gibi gözükmektedir. Bu konu başı̆̆ının "311.11-Sağlık Kurumları" içerisinde "sağılı ocağı" ve "hastanelerdeki laboratuar hizmetlerini” karşıladığı, su ve gıda raporlarıyla doğrudan ilişkisinin bulunmadığı anlaşımaktadır.

Standart dosya planında bulunmayan faaliyetlerin, planda alt konu başıklarının sonunda verilen "99-Diğer" başlığı altında değerlendirilmesi gerektiği ifade edilmektedir (Dosyalama, 2006). İlk bakışta kolaylık gibi gözükse de böyle bir açık kapının, keyfi uygulamalara sebep olabileceği gözden uzak tutulmamalıdır. Planda olmayan bir konu için "Diğer" başığı kullanılırken, aynı fonksiyonun farklı birim ve kurumlarda değişik konu başlı̆ı alma riski her zaman olacaktır. Her ne kadar kurumlarda bir kontrol mekanizması bulunacak olsa da karşılaşılan örneklerden bu kontrolün çok da kolay olmayacağı anlaşılmaktadır.

Plandaki başlıklar alt konu başlıklarına bölündükçe kullanılan kodların uygulamayı zorlayacağı anlaşımaktadır. Özellikle planda ikinci ve üçüncü alt konu başı|kları kullanmak gerektiğinde kod basamaklarının büyüdüğü görülmektedir. Bu durum, dosya kodlarını hem akılda kalıcılık gibi pratik kullanım avantajından uzaklaştırmakta, hem de kullanılacağı yer olan yazışmaların "Sayı:" kısmının aşııı büyümesine sebep olmaktadır. Ancak, planın bütün kamu idaresini kapsaması gerektiği düşünüldüğünde bu durumun kaçınılmaz olduğunu anlamak zor değildir. Bu durumda kodların aşırı büyüme riski her zaman olacaktır.

1991/17 sayılı genelgeyle uygulamaya konulan kurum kodları, yapısı gereği on dört basamaktır (Başbakanlık, 1991). Kurumdaki en alt birime kadar inmektedir. Bu alt birim kodundan sonra dosya kodu kısmı 
gelmektedir. Dosya kodundan sonra gelecek evrak kayıt numarasıyla bu alan tamamlanmaktadır.

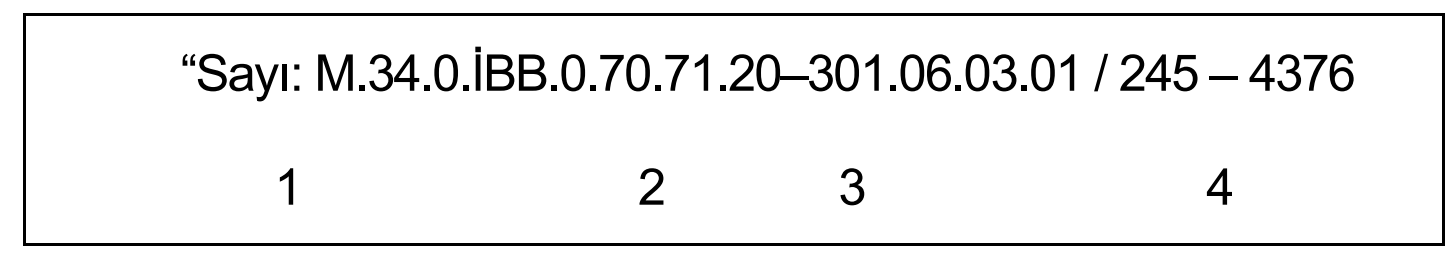

1- Kurum ve birim kodu

2- Dosya kodu

3- Birim evrak kayıt numarası

4- Kurum evrak kayıt numarası

Planda üçüncü alt konu başlığını kullanmak gerektiğinde, kod dokuz basamaklı bir sayı grubundan meydana gelecektir. Bu sıralamaya bir de evrak kayıt numarası eklendiğinde kullanımı oldukça zor bir sistemle karşı karşıya kalmak kaçınılmazdır. Görüldüğü gibi alt konu başlı̆ı açmak, teorik olarak kolay bir iş gibi gözükse de uygulamada sakıncalı sonuçlar doğurabilecek riskler taşımaktadır.

\section{Dosyalama Yönergesi ve Sorumluluk}

Bir organizasyonda belge yönetimi sisteminin yürütülebilmesi için kalifiye personel istihdamı, iyi bir dosya tasnif planı geliştirmek kadar önemlidir. Sistem uygulanabiliyorsa bir anlam ifade eder. Ne kadar mükemmel olursa olsun uygulanamayan bir sistemin karar mekanizmaları için çok da önemi yoktur. Sistemin uygulanabilir olmasını ve takibini sağlayacak olan ise hiç şüphesiz bu işten doğrudan sorumlu uzman personeldir. Bu personelin istihdamı yanı sıra gerektiği ölçüde yetki ve sorumluluk verilmesi de sitemin işlemesinde önemli bir etkendir.

Ancak, kamu idaresinde uzman belge yöneticisi istihdamının kolay olmadığı bilinmektedir. Her ne kadar norm kadro uygulamaları, kamu idaresinde arşivci ve belge yöneticisi istihdamını mümkün kılsa da dengesiz ücret dağılımı, yetersiz kariyer planlaması vb. etkenlerin, istihdamı sınırladığı görülmektedir. Ayrıca gerekli tecrübe ve mesleki donanıma sahip yetişmiş eleman bulmanın zorluğu da bir gerçektir.

SDP'nin organizasyonlarda uygulanabilmesi için uzman personel yanında yürütücü konumunda sorumlu birimin belirlenmesi gerekir. 
Planın uygulanmasını öngören genelgede "kurumların, uygulamaları takip etmek ve denetlemek üzere dosya planından sorumlu bir birim belirleyecekleri" ifade edilmektedir (Standart, 2005). Fakat bunun yardımcı hizmet birimlerinin hangisi olacağı ve nitelikleri belirtilmemiştir. $\mathrm{Bu}$ durumda sorumlu birimin nere olacağından daha çok, bu sorumluluğu kimin yürütebileceği konusu önemlidir. Çünkü arşiv müdürlüğü gibi bir birimin olmadığı yerlerde karar mekanizması takdir yetkisini kullanıp, yazı işleri veya idari işler müdürlüğü gibi bir birim belirleyebilir. Ancak, belirlenecek yerin üstleneceği fonksiyonlar itibariyle planın geliştirilip, kurum içinde uygulanmasına yardımcı olabilecek, aynı zamanda uygulamacılara yol gösterip, gelen soruları cevaplayabilecek bir birim olması gerekir.

Belirlenen birimin yetkisi ve diğer birimler üzerinde oluşturacağı etki de göz ardı edilmemesi gereken bir husustur. İdari bakımdan etkinliğinin sağlanması gerekir. Birimin doğrudan üst düzey bir karar mekanizmasına bağlı olması, belge yönetimi çalışmalarında yaptırım gücünün oluşabilmesi için gerekli bir teşkilatlanma gibi gözükmektedir.

Kamu idaresinde evrak kayıt ve dosyalama işlemleri gibi arşiv işleri de kanunla belirlenmiş belirli bir birimin sorumluluğu altındadır. Bakanlıkların kuruluş ve görevlerini belirleyen 3046 sayılı kanunda bu görev “İdari ve Mali İşler Birimi”ne verilmiştir (Bakanlıkların, 1984). Birimin görevlerinin sıralandığı 29. maddenin "k" bendinde bu husus "Genel evrak, arşiv ve haber merkezinin hizmet ve faaliyetlerini düzenlemek ve yürütmek", biçiminde ortaya konulmuştur. Arşiv hizmetlerinin yürütülmesinin öngörüldüğü bu maddeden doğal olarak SDP'nin kontrol ve takibinin de bu birim tarafından yapılacağını anlamak mümkündür.

Yönetim yapıları itibariyle belediyeler uzman personel çalıştırma konusunda diğer kamu kurumlarına göre daha avantajı konumdadır. İstanbul'da birçok belediye ve bağlı iştiraklerde arşivcilik mesleğinin eğitimini almış üniversite mezunu arşivci ve belge yöneticisi bilgi uzmanının çalıştığını görmek mümkündür (Karaduman, 2007).

IBBB'de SDP'nin uygulanması ve takip işini Arşiv Müdürlüğünün üstlenmiş olduğunu görüyoruz (Karaduman, 2007). Müdürlük, belediyede Yazı İşleri ve Kararlar Daire Başkanlığına bağıdır. Birimin, 
belediyenin teşkilat planındaki yerine bakıldığında, idari bakımdan fonksiyonel yönetim yapısına sahip bir müdürlük olduğu anlaşılmaktadır (Yönetim, 2007). Birimin görevleri ve teşkilat yapısı "Arşiv Müdürlüğü Görev ve Çalışma Yönetmeliği"nde belirtilmiştir.

Müdürlük, SDP'nin belediye birimlerinde uygulanması konusunda kendi uzman personelini görevlendirmiştir. Belediye müdürlüklerindeki SDP uygulamaları, uzman personelin denetim ve takibine bırakılmıştır. Tüm uygulamalar bu personelin gözetiminde gerçekleştirilmektedir. Her personel önceden belirlenmiş birimlerden sorumludur. Plan bu uzmanlar denetiminde uygulanmaktadır. Birimin fonksiyonlarının çıkarılıp plandaki yerinin tespit edilmesi, dosyalamanın bu ad ve koda göre yapılması, aynı zamanda dosya etiketlerinin çıkarılarak fiziksel düzenlemenin gerçekleştirilmesi birimde yapılan işler arasındadır (Güntekin, 2007).

Görüldüğü gibi standart dosya planının uygulanmasında sorumluluğun her hangi bir birim değil, doğrudan kurumun arşiv ve evrak hizmetlerinden sorumlu "arşiv müdürlüğü" veya "idari ve mali işler daire başkanlığı" gibi bir birimde olması gerekir.

Planın yürütülmesini takip edecek birim ve uzman personel yanı sıra önemli bir husus uygulama prosedürünün çıkarımasıdır. Bu prosedür, arşiv yönetmeliğinde şu şekilde ifade edilmiştir (Devlet, 1988):

\section{Dosya Planları Dosya Yönergeleri}

Madde 44- (Değişik 22/02/2005 tarihli Yönetmeliğin 5 inci maddesi ile) Mükellefler, gördükleri hizmetler, yaptıkları haberleşme ve işlemlere ait belgelerin bir arada bulunmasını sağlamak amacıyla dosya planları ile dosya yönergelerini hazırlamakla yükümlüdürler.

Mükelleflerce hazırlanacak dosya prosedürü, planın uygulanma adımlarını gösteren rehber niteliğinde bir yönergedir. Bu yönergenin hazırlanması kurumlara bırakılmıştır.

Her kurumun kendi intiyaçları doğrultusunda bir yönerge hazırlaması, ilk bakışta olumlu bir gelişme gibi gözükmektedir. Ancak, örnek bir model olmadığından birbirinden farklı dosya yönergelerinin 
çıkma intimali büyüktür. Bu sebeple SDP nasıl ki merkezi idare tarafından geliştirilmiş ise ne şekilde uygulanacağını gösteren "dosya yönergesi" de aynı mekanizma tarafından çıkarılmalıdır. Bu durum, diğerine göre daha tutarlı bir yol gibi durmaktadır. Dosya planını çıkaran kurumun uygulama şeklini de belirlemesi, bir zorunluluk değil, doğal bir sonuçtur. Çünkü planın nasıl geliştirileceği ve uygulanacağı, yeni başıkların açıması, kodların kullanılması, bu kullanımın nerede başlayacağı, kurumlarda kimlerin bu uygulamadan sorumlu olduğu ve idari bakımdan bu işin takipçisinin kim olacağı konularını en iyi uygulamayı öngören bilir. Dolayısıyla ilgili yönergenin Devlet Arşivleri Genel Müdürlüğü tarafından hazırlanması gerektiği düşünülmektedir.

Yadsınamayacak derecede önemli olduğu düşünülen bir durum da planın uygulanmasında standartlığın sağlanmasıdır. Tek elden çıkacak yönergeyle bütün mükellefler SDP aynı şekilde uygulama imkânı bulacakları gibi kurumlardaki farklı uygulamaların da önüne geçilmiş olacaktır. Aksi halde her kurum, kendi kurum kültürü, bürokratik uygulamaları ve idari yapılanmasına göre bir yönerge hazırlayacaktır.

Diğer bir husus ise örnek bir modelin bulunmamasıdır. Başka bir deyişle, mükellefler dosya planlarını geliştirirken hangi prosedürü model alacaklar. Hazırlanacak yönergenin hukuki boyutu olduğu kadar mesleki bakımdan da uzmanlık bilgisi gerektiren boyutu bulunmaktadır. Bu yönergede sadece planın uygulanması açıklanmayacak, belki de birçok terim ve terminoloji tanımlanacaktır. Bu terimlerin açıklanması uzman bilgisini gerektirecektir. Diğer taraftan yönerge belge yönetimi sistemi içerisinde bir parçadır. Dolayısıyla bu sistem içerisinde "ayıklama imha yönergesi", "belge üretim yönergesi" ve "evrak kayıt yönergesi" vb. daha başka düzenleyici işlemlere de intiyaç bulunabilir. Bu yüzden yönergenin, sistem içerisinde daha önce hazırlanmış prosedürlerle uyumlu olması gerekir. Bu uyumun sağlanması ise mesleki bilgiyle donanmış uzman personel kadrosunun bu işi koordine etmesiyle mümkündür.

Dosya planı prosedürlerinin oluşturulması bakımından IBB en şanslı kurumlardan biridir. 2001 yllında yürütülen projenin ardından hazırlanan bir dosyalama yönergesi bulunmaktadır (IBB, 2001). 
Yönerge, her ne kadar tekrar gözden geçirilip güncellemeye intiyaç gösterse de yeniden değerlendirilebilecek niteliktedir.

\section{Sonuç ve Öneriler}

Standart Dosya Planının belediyelerde uygulanması sırasında bir takım aksaklıkların yaşandığı, iç ve dış kaynaklı güçlüklerin bulunduğu görülmüştür. İstanbul Büyükşehir Belediyesinde yapılan uygulamalar göz önünde bulundurularak incelenen bu güçlükler ve üretilen çözüm yolları şu şekilde belirlenmiş̧tir.

Her ne kadar İBB'deki uygulamalar için Belediyenin Arşiv Müdürlüğünün koordinasyonuyla uzman personel görevlendirmiş olsa da yönetimin temel fonksiyonlarından biri olan insan faktörünün, SDP'de yeteri kadar dikkate alınmadığı gözlenmiştir. $\mathrm{Bu}$ yüzden diğer kurumlarda bu işin nasıl çözümleneceği cevap bekleyen bir sorudur.

Planda belediye hizmetlerine yönelik konu başlıklarının yeteri kadar fonksiyon odaklı olmadığı anlaşılmaktadır. Belediye hizmetlerine göre oluşturulması gereken başlıkların tespitinde, birim ve büro adlarının da kullanıldığı gözlenmiş̧ir. Tüm bu çabalara rağmen belediyenin asli hizmetlerinden olan çeşitli fonksiyonların planda yer almadığı görülmüştür.

Birçok organizasyonda olduğu gibi İBB'de de SDP'nin ilk uygulanan sistem olmadığı, daha önce de farklı planların denenmiş olduğu ifade edilmişti. Doğal olarak şimdiye kadar oluşan dosya ve seriler, daha önceki plana göre şekillenmiştir. Serilerin devamlı̆̆ının sağlanması bakımından önceki sistemle yeni uygulanacak SDP arasında nasıl bağlantı kurulacağı konusunun yeteri kadar açık olmadığı fark edilmiştir. Oysa bu bağlantı, yeni seriler ile eskiler arasındaki bütünlüğün teşekkülü bakımından oldukça önemlidir.

SDP'de konu başlıklarını karşılayan dosyaların türü açık bir şekilde ortaya konulmamıştır. Başılıların bir fonksiyon ya da faaliyeti karşılaması gerektiği düşünülürse, bu faaliyet sonucunda üretilecek belgeler vaka, konu ya da geçici dosya şeklindeki dosyalama türlerine göre nasıl bir dosyada düzenlenecektir. Bu durumun, planı uygulayacak 
olanlar açısından, karmaşaya sebep olacağı; vaka dosyası yerine konu, konu dosyası yerine gölge dosyaların üretilme intimalinin bulunacağı; hatta aynı vakaya ait bölünmüş dosyaların oluşabileceği görülmüştür.

Planın elektronik belgeler üzerinde nasıl uygulanacağı yeteri kadar açık değildir. Bu belirsizliğin, kurumlar arasında farklı ve keyfi uygulamalara sebep olacağı anlaşılmaktadır.

Ortaya konan bu güçlüklere çözüm olabilecek bazı öneriler ise aşağıda sıralanmaktadır:

Standart Dosya Planı kurumlarda uygulanırken mutlaka "belge yönetimi programı" içerisinde düşülmelidir. Bu program ise bir proje kapsamında gerçekleştirilmelidir.

Planın uygulanması konusunda uzun vadeli hedefler belirlenebilmesi için planda yer alan başıkların mutlaka fonksiyon odaklı olması sağlanmalıdır.

Planın hem fonksiyon odaklı olması, hem de konu başlıkları arasında bulunmayan fonksiyon ve faaliyetlerin belirlenmesi için organizasyonlarda iyi bir evrak/dosya ve fonksiyon envanter çalışması yapılmalıdır.

Fonksiyonların iş süreci adımları takip edilerek, oluşacak dosyaların türü belirlenmelidir.

Konu başlıkları tanımsal başlıklara dönüştürülmeli, anahtar kelime niteliğinde başlıklar oluşturulurken, diğer tarafta başlığın karşıladığı iş yani fonksiyonla ilgili açıklama notu niteliğinde tanımlama yapılmalıdır.

Fonksiyonel ilişkisi bulunan başlıklar ile benzer başlıklar arasında göndermeler yapılmalı, aynı göndermeler organizasyonda daha önce uygulanan dosyalama sistemindeki konu başlığı ve kodları ile SDP'ye göre verilecek başlık ve kodlar için de düşünülmelidir. 
Planın uygulanması konusunda belirlenen sorumlu birim ve personel yanı sıra gerekli takip ve kontrollerin yapılması için uzman personel görevlendirilip, yetki verilmelidir.

Organizasyonlarda daha uygulanabilir bir dosyalama sisteminin oluşması için plan üniversite gibi bilim çevrelerinde tartışılmalıdır.

İB gibi farklı kurumlarda planı uygulamaya çalışan uzmanların görüşlerine mutlaka başvurulmalıdır.

Kurumlardan alınacak geribildirimler değerlendirilmeli, gerektiğinde plan yeniden gözden geçirilip düzeltilmelidir.

Planın kâğıt evrak kadar elektronik belgeler üzerinde uygulanmasıyla ilgili temel prosedürler belirlenmeli, uygulanma şekli örneklerle açıklanmalıdır.

Planın nasıl uygulanacağıyla ilgili örnek bir dosyalama yönergesi, kurumların kendilerine bırakılmaksızın, Başbakanlık tarafından acilen çıkarılmalıdır.

Her kurumun kendi özel durumu, organik yapısı ve farklı fonksiyonlarından dolayı Standart Dosya Planının bütün örgütlerde aynı şekilde uygulanmasının mümkün olmadığı anlaşılmaktadır. İstanbul Büyükşehir Belediyesi örneğinde olduğu gibi planın uygulanması sırasında her kurumda çeşitli güçlükler yaşanacağı açıktır. Bu güçlüklerin, planın kendi içyapısından kaynaklandığı bir gerçektir. Ancak, bunların bir kısmı uygulama esnasında aşılabilecekken, uzman personel yetersizliğinden dolayı bunun mümkün olmadığı görülmüştür. Bu yüzden özellikle uygulama safhasında, uzmanlardan yardım ve profesyonel destek alınmalıdır. Durum böyle olunca, uygulamalar sırasında ortaya çıkan ve ileride çıkabilecek güçlükler, çözülemeyecek problemler olarak görülmemelidir. Bu yüzden henüz çok fazla uygulama örneği bulunmayan SDP'yi baştan uygulanamaz göstermek doğru bir yaklaşım olmasa gerekir. Planın uygulanabilirliğini tartışmak, varsa yanlışları düzeltmek ve görülen eksiklikleri gidermek, bilgi ve belge yönetimi konusunda teori ve uygulamaya dönük çalışma yapan bütün uzmanların ortak çabası olmalıdır. 
Kurumların faaliyetlerini doğru bir şekilde yansıtan fonksiyon kaynaklı bir planın ortaya çıkması, özellikle ülkenin bütün kurumlarında yapısal bakımdan tek bir standarda sahip, türü ve tanımlama bilgileri belli olan, orijinal düzeni korunmuş ve belge bütünlüğü sağlanmış dosyaların üretilmesi için iyi bir alt yapı oluşturacaktır. Bu atılım, Türkiye'de hem belge yönetimi ve arşiv uygulamalarına, hem de arşivlik malzemenin tespiti ve Devlet Arşivine gönderilmesine büyük kolaylıklar sağlayacaktır. Ortaya konacak iyi bir dosya planı modeli, özel teşebbüse ait işletmelerdeki uygulamalar için de örnek teşkil edebilir.

\section{Kaynakça}

Arşiv Müdürlüğü Görev ve Çalışma Yönetmeliği. (2007). IBB Arşiv Müdürlüğü. 22 Ekim 2007 tarihinde http://www.ibb.gov.tr/trTR/Kurumsal/Birimler/ArsivMd/Pages/AnaSayfa.aspx adresinden erişildi.

Bakanlıkların Kuruluş ve Görev Esasları Hakkında 174 Sayılı Kanun Hükmünde Kararname İle 13/12/1983 Gün ve 174 Sayılı Bakanlıkların Kuruluş ve Görev Esasları Hakkında Kanun Hükmünde Kararnamenin Bazı Maddelerinin Kaldırıması ve Bazı Maddelerinin Değiştirilmesi Hakkında 202 Sayılı Kanun Hükmünde Kararnamenin Değiştirilerek Kabulü Hakkında Kanun. (1984). Kanun no: 3046, Resmi Gazete t. 9/10/1984, s. 18540. 10 Eylül 2007 tarihinde http://www.hukuki.net/kanun/ 3046.15. text.asp adresinden erişildi.

Başbakanlık Personel ve Prensipleri Genel Müdürlüğü'nün 13/08/1991 tarih ve 08-3-383-16649 sayı ve 1991/17 numaralı genelgesi. (1993). Başbakanlık dış genelgeler (1991-1992), Ankara: Başbakanlık Personel ve Prensipleri Genel Müdürlüğü.

Biçer, A. (1999). Belediyelerde arşiv hizmetleri ve arşiv yönetmeliğinin getirdikleri (I-IV). Yerel Gündem, 1(7), 21-27; 1(8), 37-45; 1(9), 42-50; 1(10), 49-55. 
Büyükşehir ve il belediye başkanlıkları tespit ve değerlendirme formu. (2005). Devlet Arşivleri Genel Müdürlüğü. 13 Haziran 2007 tarihinde http://www.devletarsivleri.gov.tr/belediyeler/ bsbasil.htm adresinden erişildi.

Çiçek, N. (2007). Dosya tasnif planlarında fonksiyonun gücü. Serap Kurbanoğlu, Yaşar Tonta ve Umut Al (Yay. Haz.). Değişen Dünyada Bilgi Yönetimi Sempozyumu, 24-26 Ekim 2007 Ankara, Bildiriler içinde (ss. 235-244). Ankara: Hacettepe Üniversitesi Bilgi ve Belge Yönetimi Bölümü.

Devlet arşiv hizmetleri hakkında yönetmelik. (1988). 5 Ekim 2007 tarihinde http://www.devletarsivleri.gov.tr/Arsiv_mevzuati/ adresinden erişildi.

Devlet memurları kanunu (1965). Kanun No: 657, 11 Kasım 2007 tarihinde http://www.mevzuat.adalet.gov.tr/html/388.html adresinden erişildi.

Dosyalama ve standart dosya planı (2006). (Hizmete Özel), Ankara: Başbakanlık Devlet Arşivleri Genel Müdürlüğü.

Engin, B. (1962). Alman belediyeleri teşkilatının ve dosya usulünün desimâl sisteme intibakı. Idare Dergisi, 32(276), 51-54.

Eren, A. (1952). Türkiye'de modern muhaberat, dosya ve arşiv sistemleri. Iller ve Belediyeler Dergisi, 8(84), 30-32.

Eren, A. (1953a). Arşiv işleri. Iller ve Belediyeler Dergisi, 8(94), 45-48.

Eren, A. (1953b). Desimal tertipte dosya ve saire bölümü esasları ve misali. Iller ve Belediyeler Dergisi, 8(89), 39-43.

Gültekin, O. (2007). İstanbul Büyük Şehir Belediyesi Yazı İşleri ve Karar Daire Başkanlığı Arşiv Müdürlüğü Arşiv uzmanı, 15 Ekim 2007 tarihinde yapılan görüşme. 
İBB (2001). İstanbul Büyükşehir Belediyesi evrak üretim-dosyalama ve arşivleme mevzuatı. İstanbul: Belediye.

İBB (2006). Ihaleler. 25 Ağustos 2007 tarihinde http://www.ibb.gov.tr/IBB/Templates/Turkce/lhaleVellan//haleListe adresinden erişildi.

İB (2007a) İstanbul Büyükşehir Belediyesi evrak üretim-dosyalama ve arşivleme mevzuatı. İstanbul: Belediye.

IBB (2007b). Ihaleler. 25 Ağustos 2007 tarihinde http://www.ibb.gov.tr//BB/Templates/Turkce//haleVellan//haleListe adresinden erişildi.

İcimsoy, O. (2000) Belediyelerde imar dosyalarının belge profili ve arşivlerinin oluşumu: Kartal Belediyesi örneği. Arşiv Araştırmaları Dergisi, 2, 47-62.

İçişleri Bakanlığı (2006). Standart dosya planı. 25 Temmuz 2007 tarihinde http://www.icisleri.gov.tr/_Icisleri/Web/ Gozlem.aspx? sayfaNo=1 adresinden erişildi.

İçişleri Bakanlığı (2007). Bakanlığın B.05.0.BID.0.00.00.04/ 804.04/234 saylı ve 19.03.2007 tarihli "Standart Dosya Panı" konulu yazısı, Istanbul Büyük Şehir Belediyesi evrak üretim-dosyalama ve arşivleme mevzuatı, İstanbul: Belediye.

İs kanunu (2003). Kanun no: 4857. 10 Kasım 2007 tarihinde http://www.apakymm.com/isci_ozluk.doc adresinden erişildi.

Kandur, H. (2006). Elektronik belge yönetimi sistem kriterleri referans modeli (V.2.0) (gözden geçirilmiş 2.bs.). İstanbul: Devler Arşivleri Genel Müdürlüğü.

Karaduman, N. (2007). İstanbul Büyük Şehir Belediyesi Yazı İşleri ve Karar Daire Başkanlığı Arşiv Müdürlüğü Arşiv Uzmanı, 5 Ekim 2007 tarihinde yapılan görüşme. 
Kaya, Y. (2007). Yapı-Kredi Kültür Sanat Yayıncllık Ticaret ve Sanayi A.Ş. Arşiv Uzmanı, 10-13 Ekim 2007 tarihleri arasında yapılan görüşme.

Külcü, Ö. ve Külcü, H. U. (2007). Değişen koşullarda kurumsal belge ve arşiv hizmetleri: Bir uygulama örneği olarak Türkiye Kızılay Derneği. Serap Kurbanoğlu, Yaşar Tonta, Umut Al (Yay. Haz.). Değişen Dünyada Bilgi Yönetimi Sempozyumu 24-26 Ekim 2007, Ankara Bildiriler içinde (ss. 245-251). Ankara: Hacettepe Üniversitesi Bilgi ve Belge Yönetimi Bölümü.

Local government group (2007). Local government classification scheme, Records Management Society. 20 Eylül 2007 tarihinde http://www.bcs.org/server.php?show=ConWebDoc. 14082 adresinden erişildi.

Muhafazasına Lüzum Kalmayan Evrak ve Malzemenin Yok Edilmesi Hakkında Kanun Hükmünde Kararnamenin Değiştirilerek Kabulü Hakkında Kanun. (1988). Kanun no: 3473, Resmi Gazete, t. 04.10.1988, s. 19949.

Parker, E. (1999). Managing your organization's records. London: Library Association Publishing.

Saraç, S. (2007a). Standart dosya planı. Arşiv Dünyası, 9, 44-46.

Saraç, S. (2007b). Devlet Arşivleri Genel Müdürlüğü Cumhuriyet Arşivi Daire Başkanlığı görevlisi, 28 Aralık 2007 tarihinde yapılan görüşme.

Standart dosya planılya ilgili 2005/7 sayılı Başbakanlık genelgesi. (2005). 6 Aralık 2005 tarihinde http://www.devletarsivleri. gov.tr/02005-032003802.pdf adresinden erişildi. 
Stewart, J. R. ve Melesco, N. M. (2002). Professional records and information management. Newyork: McGrow-Hill.

Yönetim Şeması (2007). İstanbul Büyükşehir Belediyesi yönetim şeması. 20 Kasım 2007 tarihinde http://www.ibb.gov.tr/trTR/kurumsal/Pages/YonetimSemasi.aspx adresinden erişildi.

Ek 1. Mahalli Idarelerin Ana Konu Başıkları (İçş̧eri, 2006)

\begin{tabular}{|c|c|}
\hline 50 & Mahalli İdareler İşleri \\
\hline 51 & Mahalli İdarelerin İş ve İşlemlerine İlişkin Onaylar \\
\hline 52 & İhbar, Şikâyet ve Suç Duyuruları \\
\hline 53 & Mahalli İdarelere Mevzuatının Uygulanmasına İlişkin Görüş Talepleri \\
\hline 54 & II Özel İdaresi Bütçe İş ve İşlemleri \\
\hline 55 & Belediye Bütçe İş ve Iş̧lemleri \\
\hline 56 & Bütçe Yardımları Iş ve İşlemleri \\
\hline 57 & Raporlar ve Layihalara İlişkin İş ve İşlemleri \\
\hline 58 & Kardeş Şehirler \\
\hline 59 & Konsoloslukların İmza ve Mühür Örnekleri \\
\hline 60 & Yerel Gündem 21 \\
\hline 61 & Belediye Başkanları İş ve İşlemleri \\
\hline 62 & Belediye ve İl Özel İdaresi Kadro İş ve İşlemleri \\
\hline 63 & Mahalli İdareler ve Bakanlığımız Aleyhine Açılan Davalarla İlgili Savunmalar \\
\hline 64 & Teşkilat ve Hizmetler İş ve Iş̧lemleri \\
\hline 00 & Belediye ve Özel İdare İşleri \\
\hline 01 & Yazı ve Karar İşleri \\
\hline 02 & Encümen Çalışmaları \\
\hline 03 & Evlendirme Işseri \\
\hline 04 & Zabıta İş ve Işlemleri \\
\hline 05 & Denetimler \\
\hline 06 & Trafik İşleri \\
\hline 07 & Küşat Ruhsat Iş̧leri \\
\hline 08 & Ölçü ve Ayar İşleri \\
\hline 09 & İtfaiye İş ve İşlemleri \\
\hline 10 & Bayındırlık-Imar İş ve İşlemleri \\
\hline
\end{tabular}




\begin{tabular}{|l|l|}
\hline 11 & Çevre ve Sağlık İşleri \\
\hline 12 & Temizlik İşleri \\
\hline 13 & Yol, Köprü Yapım İşleri \\
\hline 14 & Su ve Kanalizasyon İşleri \\
\hline 15 & Ulaştırma İşleri \\
\hline 16 & Afet ve Acil Yardım İşleri \\
\hline 17 & İskân İşleri \\
\hline 18 & Eğitim ve Kültür İşleri \\
\hline 19 & Tarım Hizmetleri \\
\hline 20 & Hesap İşleri \\
\hline 21 & Ekonomik Hizmet İşleri \\
\hline 49 & Mahalli İdareler İşleri İle İlgili Diğer İşler \\
\hline
\end{tabular}

Ek 2: Görüşme soruları

Sayın Katılımcl,

Bu sorular, İB başta olmak üzere belediyelerde Standart Dosya Planının uygulanmasında yaşanan güçlüklerin belirlenmesi amacına yönelik bir çalışma için hazırlanmıştır. Sorulara vereceğiniz tarafsız ve doğru cevaplar, tamamen bilimsel amaçlar için kullanılacaktır.

1. 250-349 Konu aralığındaki belediyelere ait başlıklar yeterli mi?

2. Yeni alanlar açmaya gerek var $\mathrm{mI}$, neler?

3. Planda belediyelerin yürüttüğü fonksiyon, faaliyet ve işlemler doğru yansıtılabilmiş mi?

4. Konu kodlarının özellikle gelen yazılar üzerinde nasıl uygulanacağı açık mı?

5. Planda yer alan konu başlıklarının dosyalama anlayışı, konu ve vaka dosyası gibi dosyalama mantığına uygun mu?

6. Plan hem kâğıt hem de elektronik evrakların düzenlemesinde kullanılabilir mi? 
7. Farklı taşıyıcı ortamlar arasında uyum sağlamaya elverişli mi?

8. Gerekli açıım için "99-Diğer" başlığı yeterli mi?

9. Plan, kurumda önceden uygulanan tasnif sitemiyle ilişkiye müsaade ediyor mu?

10. Serilerin devamlılığı bakımından önceki dosya ad ve kodları ile standart dosya planındaki yeni başlıkların bütünlüğü sağlanabilmiş mi?

11. Mevcut plan, yapılması istenen dosyalama yönergesi konusuna bir açıklık getiriyor mu?

12. Planın nasıl uygulanacağı ve devamlıı̆ıyla ilgili olarak belediyelerdeki sorumlular, planlama, eğitim, uygulama ve kontrol gibi konular yeteri kadar açık mı?

13. Saklama planları konusu yeteri kadar açık mı? 